\title{
Investigation of Steven Impact Test Using \\ a Transportation Hook Projectile with Gauged Experiments and 3D Modeling
}

\author{
K.S. Vandersall, S.S. Murty, S.K. Chidester, J.W. Forbes, \\ F. Garcia, D.W. Greenwood, C.M. Tarver
}

This article was submitted to American Physical Society Topical Conference on Shock Compression of Condensed Matter Portland, OR July 20-25, 2003

U.S. Department of Energy

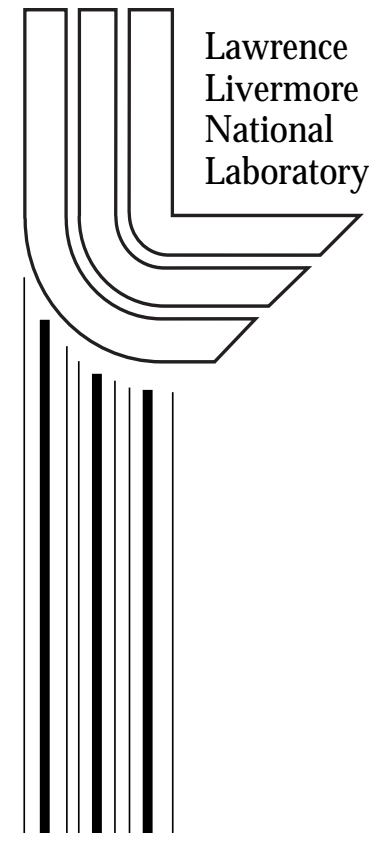

\section{July 2, 2003}




\section{DISCLAIMER}

This document was prepared as an account of work sponsored by an agency of the United States Government. Neither the United States Government nor the University of California nor any of their employees, makes any warranty, express or implied, or assumes any legal liability or responsibility for the accuracy, completeness, or usefulness of any information, apparatus, product, or process disclosed, or represents that its use would not infringe privately owned rights. Reference herein to any specific commercial product, process, or service by trade name, trademark, manufacturer, or otherwise, does not necessarily constitute or imply its endorsement, recommendation, or favoring by the United States Government or the University of California. The views and opinions of authors expressed herein do not necessarily state or reflect those of the United States Government or the University of California, and shall not be used for advertising or product endorsement purposes.

This is a preprint of a paper intended for publication in a journal or proceedings. Since changes may be made before publication, this preprint is made available with the understanding that it will not be cited or reproduced without the permission of the author.

This report has been reproduced directly from the best available copy.

Available electronically at http://www.doc.gov/bridge

Available for a processing fee to U.S. Department of Energy

And its contractors in paper from

U.S. Department of Energy

Office of Scientific and Technical Information

P.O. Box 62

Oak Ridge, TN 37831-0062

Telephone: (865) 576-8401

Facsimile: (865) 576-5728

E-mail: reports@adonis.osti.gov

Available for the sale to the public from

U.S. Department of Commerce

National Technical Information Service

5285 Port Royal Road

Springfield, VA 22161

Telephone: (800) 553-6847

Facsimile: (703) 605-6900

E-mail: orders@ntis.fedworld.gov

Online ordering: http://www.ntis.gov/ordering.htm

OR

Lawrence Livermore National Laboratory

Technical Information Department's Digital Library

http://www.llnl.gov/tid/Library.html 


\title{
INVESTIGATION OF STEVEN IMPACT TEST USING A TRANSPORTATION HOOK PROJECTILE WITH GAUGED EXPERIMENTS AND 3D MODELING
}

\author{
Kevin S. Vandersall, Susarla S. Murty, Steven K. Chidester, Jerry W. Forbes, \\ Frank Garcia, Daniel W. Greenwood, and Craig M. Tarver
}

Lawrence Livermore National Laboratory

Livermore, CA 94550

\begin{abstract}
The Steven Impact Test and associated modeling offer valuable practical predictions for evaluating numerous safety scenarios involving low velocity impact of energetic materials by different projectile geometries. One such scenario is the impact of energetic material by a transportation hook during shipping, which offers complexity because of the irregular hook projectile shape. Experiments were performed using gauged Steven Test targets with PBX9404 impacted by a transportation hook projectile to compliment previous non-gauged experiments that established an impact threshold of approximately $69 \mathrm{~m} / \mathrm{s}$. Modeling of these experiments was performed with LS-DYNA code using an Ignition and Growth reaction criteria with a friction term. Comparison of the experiment to the model shows reasonable agreement with some details requiring more attention. The experimental results (including carbon resistor gauge records), model calculations, and a discussion of the dominant reaction mechanisms in light of comparisons between experiment and model will be presented.
\end{abstract}

\section{INTRODUCTION}

The Steven Impact Test, which involves a target with High Explosives (HE) that is impacted at increasingly higher velocities with projectiles until you get a "GO" (reaction), has successfully allowed safety evaluation and modeling for accurate predictions. These velocity thresholds (lowest velocity at which you get a "GO") have been obtained on several different explosives with different projectile head geometries. One practical issue that arose was the safety of explosives in a transportation scenario where the transportation hooks that retain the apparatus could become dislodged and act as projectiles. As a very direct approach, a transportation hook was used as a projectile into a Steven test target.

Steven Impact Test research at Lawrence Livermore National Laboratory [1-6] and a modified version of this test at Los Alamos National Laboratory [7-9] involving both experiments and modeling have greatly increased the fundamental knowledge and practical predictions of impact safety hazards. The dominant microscopic mechanisms that control the initial ignition during compaction of a small volume of the explosive charge have been identified as friction, shear, and strain, 
however, the relative importance has not yet been determined experimentally. Data has been used to develop a predictive impact ignition reactive flow model based on the Ignition and Growth model for shock initiation and detonation. Further details on the modeling are discussed elsewhere [3-6].

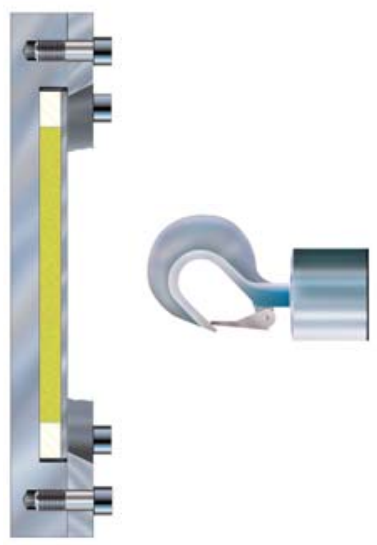

FIGURE 1. Schematic diagram showing Steven Test Target and Transportation Hook Projectile (Projectile \#5 in Steven Test Series, $1.6 \mathrm{~kg}$ ). Note that target shown is the original design and not the updated design with the PMMA outer surround ring used in this work.

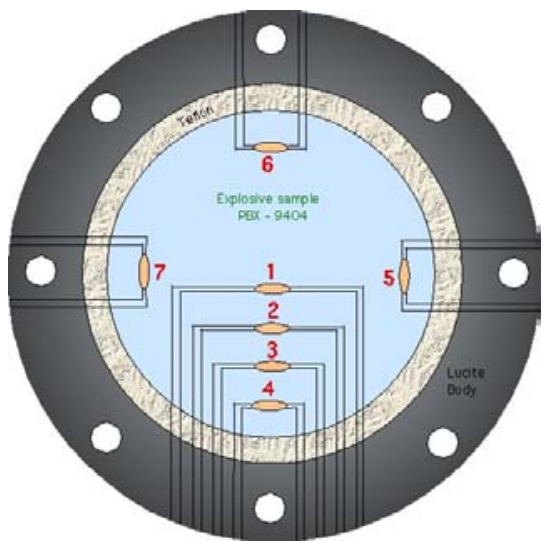

FIGURE 2. Diagram showing the carbon gauge resistor locations in the PBX9404 Steven Test Target.

\section{PROCEDURE}

Figure 1 shows a schematic of the experimental geometry of the Steven impact test target. In these tests, a $101 \mathrm{~mm}$ diameter smooth bore gas gun accelerates the projectile into the test target consisting of a $110 \mathrm{~mm}$ diameter by $12.85 \mathrm{~mm}$ thick explosive charge confined by a Teflon surround ring around the circumference, a $3.18 \mathrm{~mm}$ thick steel plate on the impact face, a $19.05 \mathrm{~mm}$ thick steel plate on the rear surface, and $26.7 \mathrm{~mm}$ thick PMMA side outer confinement. The target used in this work with a PMMA (poly-methylmethacrylate) outer confinement is a later version and slightly different than the one shown in Fig.1. The transportation hook projectile was screwed into the $6.01 \mathrm{~cm}$ diameter steel body and attached to a polycarbonate sabot. A charge of $20 \mathrm{~g} \mathrm{H} 870$ primer powder was used to accelerate the entire projectile assembly with plates of various materials and thickness attached to the back of the sabot to vary the total mass, which allowed different projectile velocities to be generated.

Carbon resistor pressure gauges $[10,11]$ were embedded into the front surface of the explosive sample. These gauges have been used successfully in previous gauged Steven Test experiments [5]. Figure 2 displays the location of the carbon resistor gauges in the PBX 9404 (94\% HMX, 3\% NC, 3\% CEF) [12] explosive sample.

\section{RESULTS/DISCUSSION}

A summary of all the hook projectile experiments with PBX9404 is located in Table I including experiment number, projectile velocity, sabot mass, and whether reaction occurred. Experiments WRL203-206 were equipped with carbon resistor gauges. Note that experiment WRL204 showed reaction, whereas the WRL185 did not show reaction at the same $67 \mathrm{~m} / \mathrm{s}$ velocity. It is assumed that this is due to the presence of the gauges influencing the 
amount of friction during impact and therefore contributed to the reaction. It was desired to get a low enough velocity to not get a reaction, but only four targets were readily available and because of the system used, precise control over a desired velocity was unobtainable. The reaction threshold is still considered to be 69 $\mathrm{m} / \mathrm{s}$, because thresholds are formulated using standard (non-gauged) test results.

Figure 3 displays output gauge records for experiment WRL204 (solid lines). Records for experiments WRL203 and WRL205 showed similar behavior as expected from the similar impact velocity (Table I). From camera images these three experiments can be qualitatively described as "slight GO's" just based on the size of the reaction fireball. As could be reasonably expected, gauge survivability proved to be a problem with the hook impact. In describing the three similar gauged experiments (WRL203205), the outer gauges tended to survive longer whereas the gauges close to the hook impact (gauges 1-3) tended to get destroyed early. The peaks in these outer gauges tended to be in the range of 0.3 to $0.4 \mathrm{kbar}$.

(a)

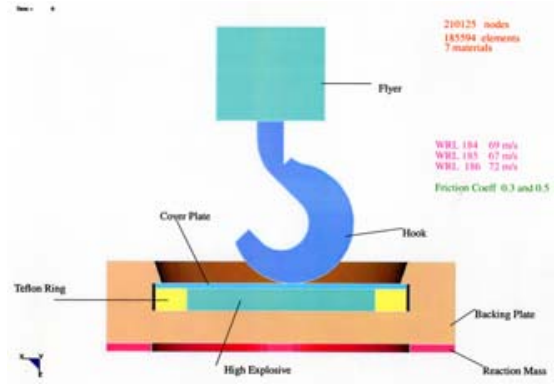

b)

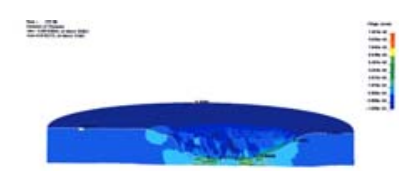

FIGURE 4. a) Schematic of the material placement in the LS-DYNA code and b) view of the PBX9404 material after running the code.
TABLE I. Summary of all hook projectile experiments. Experiments WRL203-206 had in-situ carbon resistor gauges.

\begin{tabular}{||c|c|c|c||}
\hline EXPT & VELOCITY & $\begin{array}{c}\text { SABOT } \\
\text { MASS }(\mathrm{kg})\end{array}$ & REACTION? \\
\hline WRL183 & $37 \mathrm{~m} / \mathrm{s}$ & 3 & NO \\
\hline WRL184 & $69 \mathrm{~m} / \mathrm{s}$ & 2.4 & YES \\
\hline WRL185 & $67 \mathrm{~m} / \mathrm{s}$ & 2.7 & NO \\
\hline WRL186 & $72 \mathrm{~m} / \mathrm{s}$ & 2.5 & YES \\
\hline WRL203 & $68 \mathrm{~m} / \mathrm{s}$ & 2.7 & YES \\
\hline WRL204 & $67 \mathrm{~m} / \mathrm{s}$ & 2.5 & YES* \\
\hline WRL205 & $69 \mathrm{~m} / \mathrm{s}$ & 2.32 & YES \\
\hline WRL206 & $125 \mathrm{~m} / \mathrm{s}$ & 2.32 & YES \\
\hline
\end{tabular}

*Note that $67 \mathrm{~m} / \mathrm{s}$ reacted in instrumented experiment but not in the experiment without gauges.

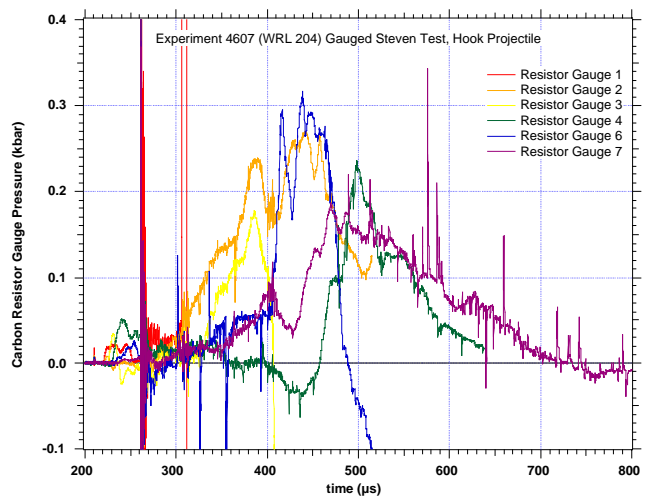

FIGURE 3. Gauge records for experiment WRL204 that are similar to records in experiments WRL203 and WRL205.

As noted in Table 1, a higher velocity experiment (WRL206) was performed at 125 $\mathrm{m} / \mathrm{s}$ impact with a reaction. The gauge records (not shown) revealed a nice peak on the first gauge up to about $1 \mathrm{kbar}$, and a peak on outer gauges to about 0.45 kbar before gauge failure occurred. As mentioned above, gauge survivability was a problem, especially at this high velocity.

Modeling of these experiments was performed with LS-DYNA [13] running in 3D with Ignition and Growth reaction criteria and a friction term. As a start, the $67 \mathrm{~m} / \mathrm{s}$ NOGO test was run. Note that since this was a slight GO in 
gauged experiment, the direct comparison will not be completely relevant, but it is expected that the results should be comparable. The gauge records from the model output are shown in Fig. 3 as dashed lines. Figure 4(a) and (b) shows the material placement in the LS-DYNA model and contour plot of the PBX9404 well into a run, respectively. It can be seen that at gauge locations the peak pressure is about 1.6 kbar in center to $1 \mathrm{kbar}$ on periphery. These pressures are higher than those measured in the experiment. Understanding these differences is currently in progress, and a strain rate dependent and futher improved material model is in the works. The next step after getting closer agreement with this velocity $(67 \mathrm{~m} / \mathrm{s})$ is progressing to the $69 \mathrm{~m} / \mathrm{s}$ case.

\section{SUMMARY AND FUTURE WORK}

Experiments were performed using gauged Steven Test targets with PBX9404 impacted by a transportation hook projectile to compliment previous non-gauged experiments. Modeling of these experiments was performed with LSDYNA code. Comparison of the experiment to the model shows reasonable agreement with more work needed. Future work includes more work to refine the modeling, including incorporation of a strain rate sensitive material model in LS-DYNA. Additional modeling with ALE3D Code for comparison/verification is also desired.

\section{ACKNOWLEDGEMENTS}

The $101 \mathrm{~mm}$ gun crew at the High Explosives Applications Facility: Ernie Urquidez, Brian Cracciola, and Gary Steinhour are thanked for their hard work. Funding provided from Defense Technologies Engineering Division (DTED) at LLNL. This work was performed under the auspices of the U. S. Department of Energy by the University of California, Lawrence Livermore National Laboratory under Contract No. W-7405-Eng-48.

\section{REFERENCES}

1. Chidester, S.K., Green, L.G., and Lee, C.G., Tenth International Detonation Symposium, ONR 3339512, Boston, MA 1993, pp. 785-792.

2. Chidester, S. K., Tarver, C. M., and Lee, C. G., Shock Compression of Condensed Matter-1997, edited by S.C. Schmidt et. al., AIP Conference Proceedings 429, AIP Press, New York, 1998, pp. 707-710.

3. Chidester, Steven K., Tarver, Craig M., and Garza, Raul, Eleventh (International) Symposium on Detonation, ONR 33300-5, Arlington, VA, 1998 , pp. 93-100.

4. Chidester, S. K., Tarver, C. M., DePiero, A. H., and Garza, R. G., Shock Compression of Condensed Matter-1999, M.D. Furnish, L. C. Chhabildas, and R. S. Hixson, eds., AIP Conference Proceedings 505, New York, 2000, P. 663-666.

5. Niles, A. M., Garcia, F., Greenwood, D. W., Forbes, J. W., Tarver, C. M., Chidester, S. K., Garza, R. G., and Switzer, L. L., Shock Compression of Condensed Matter-2001, Furnish, M. D., Thadhani, N. N., and Horie, Y, eds. CP620, AIP Press, New York, (2002).

6. Kevin S. Vandersall, Steven K. Chidester, Jerry W. Forbes, Frank Garcia, Daniel W. Greenwood, Lori L. Switzer, and Craig M. Tarver, Proceedings of the 12th International Detonation Symposium, San Diego, CA, August, 2002, in press.

7. Idar, D. J., Lucht, R. A., Straight, J. W., Scammon, R. J., Browning, R. V., Middleditch J., Dienes, J. K., Skidmore, C. B., and Buntain, G. A., Eleventh International Detonation Symposium, Aspen, $\mathrm{CO}$, 1998, pp. 101-110.

8. Scammon, R. J., Browning, R. V., Middleditch, J., Dienes, J. K. Haverman, K. S., and Bennett, J. G., Eleventh International Detonation Symposium, Aspen, CO, 1998, pp. 111-118.

9. Browning, R. V., Shock Compression of Condensed Matter-1995, S. C. Schmidt and W. C. Tao, eds, AIP Press, New York, 1996, p. 405-408.

10. R.W. Watson, Rev. Sci. Instrum. 38, 978 (1967).

11. Ginsberg, Michael J., and Asay, Blaine W., Rev. Sci. Instrum. 62 (9): 2218-2227 (1991).

12. Dobratz, B.M. and Crawford, P.C., LLNL Explosives Handbook, LLNL Report UCRL-52997 change 2, 1985.

13. LS-DYNA Keyword User's Manual, Version 960, Livermore Software Technology Corporation, March 2001. 